\title{
Teaching Sustainable Development Goals to University Students: A Cross-Country Case-Based Study
}

\author{
Clara Vasconcelos ${ }^{1, *(\mathbb{D}}$, Joana Silva ${ }^{2}$, Cristina S. C. Calheiros ${ }^{2}\left(\mathbb{D}\right.$, Grzegorz Mikusiński $^{3}{ }^{(D)}$, \\ Katarzyna Iwińska ${ }^{4, *(\mathbb{D})}$, Ioanna G. Skaltsa ${ }^{5}$ and Katarzyna Krakowska ${ }^{4}(\mathbb{D}$
}

Citation: Vasconcelos, C.; Silva, J.; Calheiros, C.S.C.; Mikusiński, G.;

Iwińska, K.; Skaltsa, I.G.; Krakowska,

K. Teaching Sustainable

Development Goals to University

Students: A Cross-Country

Case-Based Study. Sustainability 2022,

14, 1593. https://doi.org/10.3390/

su14031593

Academic Editors: Alexandros

Stefanakis, Henrique Pinho

and Dina Mateus

Received: 22 December 2021

Accepted: 26 January 2022

Published: 29 January 2022

Publisher's Note: MDPI stays neutral with regard to jurisdictional claims in published maps and institutional affiliations.

Copyright: () 2022 by the authors Licensee MDPI, Basel, Switzerland. This article is an open access article distributed under the terms and conditions of the Creative Commons Attribution (CC BY) license (https:// creativecommons.org/licenses/by/ $4.0 /)$.
1 Interdisciplinary Centre of Marine and Environmental Research (CIIMAR), Science Teaching Unit (UEC) \& Department of Geosciences, Environment and Spatial Planning (DGAOT), Faculty of Sciences (FCUP), University of Porto, 4169-007 Porto, Portugal

2 Interdisciplinary Centre of Marine and Environmental Research (CIIMAR), University of Porto, 4450-208 Matosinhos, Portugal; joanamfsilva@fc.up.pt (J.S.); cristina@calheiros.org (C.S.C.C.)

3 School for Forest Management, Swedish University of Agricultural Sciences SLU, 739-21 Skinnskatteberg, Sweden; grzegorz.mikusinski@slu.se

4 Institute of Sociology, Collegium Civitas, Pl. Defilad 1, 00-901 Warsaw, Poland; katarzyna.krakowska@civitas.edu.pl

5 Department of Agricultural Economics \& Rural Development, School of Food, Biotechnology \& Development, Agricultural University of Athens (AUA), 75, Iera Odos, 11855 Athens, Greece; ioanna@aua.gr

* Correspondence: csvascon@fc.up.pt (C.V.); katarzyna.iwinska@civitas.edu.pl (K.I.); Tel.: +351-22-0402462 (C.V.); +48-226-567-187 (K.I.)

\begin{abstract}
With the purpose of analysing if case-based teaching methodology could improve higher education students' knowledge about sustainable development, a quasi-experimental study was conducted in an international project (PASSION_Partnership for Sustainable Development and Social Innovation) and in five countries (Greece, Poland, Portugal and Sweden). Cases were interdisciplinary and focused on sustainable development goals aligned with common worldwide dilemmas like, for example, food consumption, organic farm or nature protection. Our sample consisted of 104 university students aged between 18 and 58 years, where $53 \%$ were female. Standardized pre- and post-tests were administered, and a significant improvement in sustainable development knowledge was observed considering three main questions in the pooled dataset $\left(\mathrm{t}_{103}=-7.324 ; p=0.000\right)$. Regarding the four cases applications where results were more significant, an in-depth analysis was conducted, allowing the project team to better understand participants answers to multiple-choice and open questions which are analysed and discussed individually. Our results demonstrate that the case-based teaching improved the knowledge of sustainable development goals, which is expected to induce positive changes in pro-environmental behaviours. We also point out the potential of case-based teaching applied in a cross-country manner. The scheme is particularly valuable in dealing with complex sustainability dilemmas that show better their global perspectives.
\end{abstract}

Keywords: sustainability; case-based teaching; higher education; international project; pro-environmental behaviours

\section{Introduction}

The 2030 Agenda for Sustainable Development was prepared and published in 2015 by the United Nations to guide citizens and institutions towards a more sustainable path, to promote the solution to contemporary problems. It also intended to ensure the security of both people and the planet, by encouraging audacious steps in the economy, society and the environment [1]. Since then, sustainable development has been considered one of the most important areas of focus in contemporary society, despite its complexities, especially regarding a large number of different stakeholders (from businesses, governments, non-governmental organizations, and universities), that must all cooperate in unity and 
harmony in order to successfully implement the required changes to achieve sustainability $[2,3]$. Further, considering the 2030 Agenda's goals the current social and environmental contexts have been worsening over the years and are reflected in the degradation of the natural environment, unsustainable use of non-renewable resources and its subsequent effects on the climate conditions and the aggravation of already existing inequalities [4]. As such, citizens must be equipped with the knowledge and skills necessary to face and overcome the challenges that are presented to them every day. Therefore, and as proposed by the United Nations Educational, Scientific and Cultural Organization (UNESCO), Education for Sustainable Development (ESD) becomes essential in the education and empowerment of students. Citizens alike, regarding sustainable development and the profound transformations necessary to achieve the 17 Sustainable Development Goals (SDGs) delineated in the previously mentioned 2030 Agenda [1,5-10]. Therefore, ESD should be a ubiquitous model of education in the 21st century to provide all students with the opportunity to develop the necessary competencies to make individual and collective choices aligned with sustainable development. It should not only allow citizens to make sustainable decisions, but it also should help them to understand how these affect the future of the planet and, consequently, living conditions of upcoming generations. As stated by some authors "the solution-resistance challenges to sustainability that arise at the intersection of intertwined and complexity interacting natural and human systems demand innovative thinking regarding the nature and purpose of education" [11]. Furthermore, other authors [9] highlight the importance and impact of interdisciplinarity and collaboration with other stakeholders in Education for Sustainable Development (ESD), enhancing the development of important competencies, which cannot be directly taught. ESD intends to develop pro-sustainable behaviours that are often confused with pro-environmental behaviours (PEB). Pro-sustainable behaviours differ from PEB by incorporating the social and economic dimensions. PEB are defined as behaviours with explicit aims to protect the natural environment from the harmful effects of human activity [12].

Amongst the various stakeholders mentioned earlier and considering the significance of ESD in promoting responsible citizenship, universities can play a vital and unique role in endorsing sustainable development. Research shows that SDGs are rarely addressed within institutions reinforcing the need to develop actions focused on future teachers' training, managers' professional development and promoting social innovators [13,14]. This action may ensure that within the institution SDGs are addressed and highlighted, which is not always the case [6]. And, although many universities are encouraging a path towards sustainability and the implementation of SDGs, as defined in Agenda 2030, it seems that depending on the nature of the educational institution and of the degree programmes that are available, they are doing it very differently. Due to that fact, in the end, they may reflect on different levels of SDGs knowledge amongst students $[6,9,15]$. Taking into account that sustainability is a global issue demanding joint efforts of various levels and fields of expertise, it becomes crucial to find new ways to promote awareness and understanding for pro-environmental behaviour. This, in turn, demands more holistic and joint actions that can be ensured by the development and implementation of interdisciplinary projects. Some researchers refer that "ESD is interdisciplinary and addresses both learning content and pedagogy. It includes key sustainability topics (e.g., poverty, reduction, sustainable consumption, climate change and disaster risk reduction) and student-centred, participatory, and action-oriented approaches to teaching and learning" [11]. The project Partnership for Sustainable Development and Social Innovation (PASSION) has adopted such approach. PASSION is an international project based on the cooperation of researchers and academic teachers from six countries (Greece, Iceland, Poland, Portugal, Sweden, and the United Kingdom) interested in ESD. One of the PASSION's main aims was to evaluate teaching materials on education for sustainability, which had been previously developed within the scope of a different, yet related project: Widening Interdisciplinary Sustainability Education (WISE). The WISE project is another example of an initiative towards endorsing the sustainable development by providing teachers and students with resources to expand 
their knowledge, as well as to explore and enhance their competencies regarding sustainability [16]. Moreover, project Geoethics Outcomes and Awareness Learning (GOAL) was developed by some members of PASSION project and also aimed to demonstrate the importance of sustainability through developing cases, namely those related to geoethics and geosciences [17]. All these projects seek to aid students in the development of important competencies, such as problem-solving and decision-making, in relation to sustainable development. The aforementioned teaching materials evaluated in the PASSION project consist of a series of cases developed by the project partners, namely cases related to sustainability issues within the various national contexts of the PASSION partners.

The problem of the present research was to verify if the case-based teaching methodology could improve higher education students' knowledge about sustainable development. As such the present study aimed to describe the evaluation of the sessions were the teaching materials on sustainability education developed by the PASSION project team members. Then, taking the challenge of scrutinizing the differences between countries and universities, we analyse the results of the sessions implementations in five project partner's universities. After presenting results of pre-test and post-test we discuss our findings and conclude with some recommendations for the future use of case-based methods.

\subsection{Case-Based Teaching}

Over a century ago, the law and business schools of Harvard University, real-world cases began to be used in classes by Christopher Langdell instead of the traditional teaching approaches, revolutionizing the way that classes were taught at that time $[18,19]$. Today, case-based academic teaching is well established and widely applied worldwide and across many disciplines, from biology and geology to engineering and medicine, as well as law and business, where it first began [20,21]. Case-based teaching is a methodology grounded on an active and student-centre class as advocated by socio-constructivism. The potentialities of reflection, critical-thinking, group discussion, opinion-forming and argumentation makes this methodology unique and able to form active citizens. After analysing specific cases and with the mediator role of the instructor, learners develop the capacity of recognizing patterns and improve problem-solving skill though several real scenarios. According to some authors [22] various terms are used to refer to casebased teaching such as: 'case-study pedagogy' [23]; 'case-study method' [24]; 'case-study instruction' [24,25]; 'case discussion as pedagogical method' [26]; and 'case reading and discussion' [27]. In this study, the term "case-based teaching" refers to both the case and the teaching that happens as a result of the case use. Unlike the more traditional transmissive model of teaching, where the knowledge flows from the teacher to the students without much, or any, active participation from the latter, case-based teaching shifts the role of the teacher from a simple distributor of knowledge to someone who facilitates the learning that students can do for themselves in a much more active way. Case-based teaching is also recognized as an effective over the traditional method in teaching and learning arising interest and encouraging self-directed learning [28]. By using cases, which are based on the real-world situations that students are familiar with in their daily lives and by mobilizing previous knowledge to solve the problems presented to them, case-based teaching is tapping into students' natural curiosity and enhancing their critical-thinking skills [29]. In case-based teaching, students are presented with real-life scenarios and instructed to identify answers to the questions posed, preferably in groups. As suggested by some authors [30] this methodology follows the idea that new knowledge is built upon previous knowledge by associating it with experience. Therefore, case-based teaching provides students with an opportunity to actively relate previously acquired knowledge with real-life situations, which can also aid students in memorization by providing them with mental anchors for the concepts they are meant to assimilate [31].

The advantages of using case-based teaching as a vehicle for learning are well known and include subject-specific and general knowledge. Case-based teaching also intends to foster the development of specific competencies, such as those related to collabora- 
tion, communication, and decision-making, given that often cases are approached and addressed by students in groups, allowing for many opinions and points of view to be explored during the discussion [32]. It develops critical thinking, collaborative learning, and communication skills [33]. Case studies typically involve the student in an analytical, reasoning, and decision-making process, as well as in small and large group discussions to enable engagement with others and presentations to improve communication skills. Thus, to achieve the above, cases can either be presented to the students as examples, as an opportunity to analyse a situation and develop a plan of action or offered as a means to individual reflection, which, initially, results in a more meaningful learning [19].

According to some authors [21] there are five key characteristics of the cases: (1) the cases must be based in real life situations, (2) the cases must be based on thorough research and study, (3) the cases must allow for the development of various perspectives during the discussion, resulting from different thoughts and arguments, (4) the case must be explored interactively by the students, and (5) the case must direct students towards a conclusion through using necessary resources and dynamic discussions. Merseth [34] proposes three uses for cases: (a) as exemplars or models of best practices that demonstrate theoretical principles in action; (b) as opportunities for analysis of complex teaching situations and decision-making practice and (c) to stimulate reflection and help pre-service teachers develop reflective practice skills.

It is important to highlight, however, that there are two essential elements of casebased teaching, and only one of them is related to the cases themselves. The first can simply be defined as the case (the story or the scenario) and resources that the students work with and explore. The second is related to the teaching and learning strategies to be implemented in the classroom and which are meant to guide the students through the exploration of the case such as, for example, the questions and specific time for discussing and sharing ideas. Further, the teacher also plays an important role in the facilitation and promotion of the process by posing questions and mediating debates, and, according to the nature of the case, resorting to adequate strategies to engage students in the process such as, for example, field trips, laboratory work and role-playing [19]. These elements are necessary and needed to be worked in harmony with each other in order to successfully apply a case [31]. By the end of the case exploration, students are often requested to evaluate each other's arguments and solutions to the case in a plenum discussion which further enables the development of the aforementioned competences.

Case-based teaching is particularly useful in the case of ESD concerning the 2030 Agenda for Sustainable Development and the pathway towards the achievement of its SDGs. SDGs calls for educational frameworks which allow learners to learn actively and promote both responsibility and accountability, as well as the capacity of understanding how the knowledge is linked to real-life situations and how one's actions may deeply impact the future [35].

In sum, case-based teaching can be a successful and meaningful methodology in the education of responsible citizens capable of understanding the complexity and urgency of contemporary problems and steering humanity towards sustainability.

\subsection{Cases and Sustainable Development Goals}

Within the project's scope, five different cases were implemented in four countries: Greece, Poland, Portugal, and Sweden. A brief description and outline of the diverse implemented cases, as well as of the SDGs that each of them covers, is presented below. These cases have been developed previously within the framework of the WISE project [36] and are based on the research interests of the project's participants. Our general expectation was that through studying the above cases, the students would develop a better understanding of sustainable development goals. Implementation of all the cases started with the same pre-test adhering to sustainable development and was concluded by post-test. Out of totally developed five cases thematically covering multiple SDGs, four were selected to be tested. 


\subsubsection{Dead Wood in the Białowieża Forest}

The case "Dead wood in the Białowieża Forest" concerns the conservation issues of the iconic Białowieża Forest located in Poland. The perception of the case is polarized [37]. The first perspective pertains to the assumption that the forest's biodiversity could be maintained without the need for human intervention, where the most important factors are the existing ecological processes. The second perspective postulate that existing forest biodiversity values of Białowieża Forest are largely an outcome of long-term human actions, i.e., active forest management including logging and planting trees. Despite the two perspectives, both sides have the same goal: to save the Białowieża Forest. The conflict surrounding the conservation of the biodiversity in the forest became particularly dramatic due to the outbreak of the spruce bark beetle that resulted in large quantities of new dead wood and elevated logging of the precious forest [38]. The students are first introduced to the case by the instructor. Next, they are asked to prepare themselves for the role-play exercise with the representation of different stakeholders involved in the conflict. Finally, they openly discuss their stakeholders' role-playing experience from a meta-level. The case intends to increase awareness regarding the complexity of biodiversity conservation amongst the participants. The central theme of this case was connected to biodiversity conservation SDG 15 (Life on land); however, it also incorporates four other SDGs: SDG 3 (Good health and well-being), SDG 7 (Affordable and clean energy), SDG 8 (Decent work and economic growth), SDG 11 (Sustainable cities and communities).

\subsubsection{Organic Olive Cultivation in Messinian Mani, Peloponnese}

The "Organic olive cultivation in Messinian Mani, Peloponnese "case explores the discussion within the EU regarding the subsidization of organic farming referred in some studies [39]. It intends to simulate the stakeholders' dialogue process as a way of public participation in decision-making. In this case, students are encouraged to discuss the pros and cons of policy instrument from the various stakeholders' points of view, synthesizing among differing opinions, in order to find a common ground for the developmental process. The teaching adopted the experiential learning approach and Kolb's circle stages: Concrete Experience, Reflective Observation, Abstract Conceptualization, and Active Experimentation [40]. Strategies resorted to video presentation, role-playing, short lecture, group work, brainstorming and discussion. Due to online teaching and in order to enhance the participatory procedures, the Mural and Kahoot application were used. To support students' skills like teamwork, communication, presentation a one-hour preparatory online meeting was offered. In this meeting, the role-playing strategy was introduced thought participatory activities and energizers and students were divided into four groups (each one with a specific role). During the classes the students collaborated under the perspective of their role and in order to identify dilemmas and present their arguments on a scenario regarding subsidization of organic farming. The case includes six SDGs: SDG 1 (No poverty), SDG 3 (Good health and well-being), SDG 6 (Clean water and sanitation), SDG 10 (Reduced inequality), SDG 12 (Responsible consumption and production), SDG 15 (Life on land) and SDG 17 (Partnership for the Goals).

\subsubsection{Sustainable Food Consumption-Mitigating Food Waste}

The main topic of this case is the generation of food waste and its impact on different dimensions of sustainability. The main teaching aim was to present the food chain system by providing students with the forecasts of agricultural land growth to satisfy increased food demand if food production, diet, and food waste do not change. Research shows that cropland areas may need to be 10 to $25 \%$ greater by 2050 than they were in 2005 [41]. As a result, one of the primary problems of the twenty-first century is to reconcile global food production with biodiversity protection [42,43]. It is the students' challenge and aim to identify the dilemmas of consumers as they attempt to reduce food waste. Firstly, the participants of the case are invited to learn what food waste is and what its impact is on the economy, society, and the environment, both locally and globally. Then, students are 
invited to propose solutions to mitigate the food waste problem, assessing the costs and benefits of determined actions regarding food waste. The case also focuses on the students changes of behaviour in the matter. Students are encouraged to take action against food waste in their lives, given the knowledge and skills demonstrated. This case deals with the following five SDGs: SDG 2 (Zero hunger), SDG 3 (Good health and well-being), SDG 4 (Quality education), SDG 10 (Reduced inequalities), SDG 12 (Responsible consumption and production).

\subsubsection{Remodelling an Ancient Farm}

The case "Remodelling an ancient farm" is focused on the remodelling of an ancient family farm in the north of Portugal towards improved sustainability, simultaneously promoting rural tourism and pre-serving the farm's cultural identity. It intends to demonstrate how sustainable tourism should work in balance with the natural environment and the community to manage the economic, social, and environmental resources. This type of tourism is gaining interest towards a sustainable development. This approach is thus of outmost relevance involving rural resources for local socio-economic benefits, environmental protection, local community empowerment and engagement, preserving the cultural and historical characteristics of the material and immaterial heritage $[44,45]$. The crucial aspects tackled are the culture and local traditions that generate economic and social benefits. Groups of students, each representing different stakeholders (ecological association, citizens that support migrants' inclusion, town hall, economists, and family farm) with different needs and interests, are invited to participate in a role-playing exercise that aims to develop knowledge and competencies. The cultural heritage is of particular focus. Groups are asked to discuss the topic together and find arguments to support their decisions after having access to specific supporting materials that were developed for this purpose. This process allows students to work collaboratively. The discussion is facilitated by a mediator allowing each team to present arguments to support their own points of view. Finally, the team that represents the family that owns farm shares with all groups the final, sustainable decision taken. Further, this case seeks to fully integrate the economic, social, and environmental dimensions of sustainable development. In the end, the case aims to empower students to be able to take sustainable actions integrating four SDGs: SDG 3 (Good health and well-being), SDG 9 (Industry, innovation, and infrastructure), SDG 11 (Sustainable cities and communities), and SDG 15 (Life on land).

\subsubsection{Transformation of a Local Production Company into a Sustainable Business}

The "Transformation of a local production company into a sustainable business" case deals with a company, started in 1990, during the wave of Polish economic transformation after the collapse of the Soviet-imposed socialist system. The company concentrated entirely on manufacturing grinding balls for ore enrichment units in raw material mines and the power industry in the mid-1990s. In 1997, the company gained the status of a protected workplace, as over half of its employees have disabilities. A Protected workplace is an enterprise that employs minimum $50 \%$ of people with disabilities. The status of such a company gives additional profits (receives subsidy and some tax/loan ease) but also needs to face strict requirements. The case is presented from the point of view of the current leader of the company: a woman who inherited the company and had to operate in the traditionally male field of business located in the patriarchal community of middle size town in eastern Poland. Her main motivation was to keep it simple and cost-effective to achieve a more sustainable business [46]. The entire process plan incorporates an energysaving technique based on heating the material just once (in two stages: pre-heating and then heating-up), as well as the continued usage of scrap resources. Also, and taking in consideration some authors [47], the benefits for employees with disabilities were a priority. The participants in the session are involved in a discussion on the challenges of management taking into account the complex factors presented from the perspective of the new owner of the company. They are asked to propose a development strategy plan for the 
company, using sustainability concepts to suggest new approaches and also discuss some tactics for a women working in the "men-dominated" environment. The case includes five different SDGs: SDG 5 (Gender equality), SDG 8 (Decent work and economic growth), SDG 9 (Industry, innovation, and infrastructure), SDG 10 (reduced inequalities), and SDG 12 (Responsible consumption and production).

\section{Materials and Methods}

A quasi-experimental study was applied resorting to case-based teaching sessions to test the above-mentioned teaching materials in four countries-Portugal, Greece, Poland, and Sweden. The hypothesis that the sessions with the educational resources significantly improve the sustainable development knowledge of higher education students was analysed with statistical tests presented in the results' section.

Our sample consisted of 104 university students with ages ranging from 18 to 58 years, the majority females (53\%). It should be noticed that the total number of students involved in teaching sessions was higher, but in this study, we only considered the students that participated in both pre- and post-test. Table 1 shows the characterization of the study sample.

Table 1. Characterization of the sample.

\begin{tabular}{|c|c|c|c|c|}
\hline Country & Gender & Degree Program & Course Study & $\begin{array}{c}\text { Age } \\
\text { (Range, Average) }\end{array}$ \\
\hline $\begin{array}{c}\text { Greece } \\
(n=38,20 \%)\end{array}$ & $\begin{array}{c}\text { Male }(n=14,37 \%) \\
\text { Female }(n=24,63 \%)\end{array}$ & Bachelor's $(n=38,100 \%)$ & $\begin{array}{l}\text { Rural Economy and } \\
\text { Development }(n=20,53 \%) \\
\text { Other }{ }^{1}(n=18,47 \%)\end{array}$ & $\begin{array}{r}18-30 \\
M=25\end{array}$ \\
\hline $\begin{array}{c}\text { Poland }^{2} \\
(n=21,20 \%)\end{array}$ & $\begin{array}{c}\text { Male }(n=12,57 \%) \\
\text { Female }(n=9,43 \%)\end{array}$ & $\begin{array}{c}\text { Bachelor's }(n=14,67 \%) \\
\text { Master's }(n=7,33 \%)\end{array}$ & $\begin{array}{c}\text { Management }(n=12,57 \%) \\
\quad \text { Sociology }(n=7,33 \%) \\
\text { International Relations }(n=2,10 \%)\end{array}$ & $\begin{array}{r}19-58 \\
M=26\end{array}$ \\
\hline $\begin{array}{l}\text { Portugal }^{3} \\
(n=24,23 \%)\end{array}$ & $\begin{array}{c}\text { Male }(n=9,38 \%) \\
\text { Female }(n=14,58 \%) \\
\text { Other }(n=1,4 \%)\end{array}$ & $\begin{array}{l}\text { Bachelor's }(n=1,4 \%) \\
\text { Master's }(n=23,96 \%)\end{array}$ & $\begin{array}{l}\text { Biology and Geology Teacher } \\
\text { Education } \\
(n=24,100 \%)\end{array}$ & $\begin{array}{r}22-58 \\
M=31\end{array}$ \\
\hline $\begin{array}{c}\text { Sweden } \\
(n=21,37 \%)\end{array}$ & $\begin{array}{l}\text { Male }(n=13,62 \%) \\
\text { Female }(n=8,38 \%)\end{array}$ & $\begin{array}{c}\text { Bachelor's }(n=19,91 \%) \\
\text { Master's }(n=2,9 \%)\end{array}$ & $\begin{array}{c}\text { Forest Management }(n=19,91 \%) \\
\text { Sociology }(n=2,9 \%)\end{array}$ & $\begin{array}{r}20-32 \\
M=25\end{array}$ \\
\hline $\begin{array}{l}\text { All countries } \\
(n=104,100 \%)\end{array}$ & $\begin{array}{c}\text { Male }(n=48,46 \%) \\
\text { Female }(n=55,53 \%) \\
\text { Other }(n=1,1 \%)\end{array}$ & $\begin{array}{l}\text { Bachelor's }(n=72,69 \%) \\
\text { Master's }(n=32,31 \%)\end{array}$ & & $\begin{array}{r}18-58 \\
M=25\end{array}$ \\
\hline
\end{tabular}

${ }^{1}$ Plant Production Science, Animal Production and Aquaculture Science, Biotechnology, Food Science and Human Nutrition, Natural Resources Utilisation and Agricultural Engineering ${ }^{2}$ Citizenship: Polish $(n=20)$, Ukrainian $(n=1)^{3}$ Citizenship: Portuguese $(n=22)$, Brazilian $(n=2)$.

\subsection{Sample}

The sample included graduate students and master students with no particular sustainability development background. The authors wanted to analyse the impact of sustainability knowledge development in students with no (or few) prerequisites taught in a specific content of formal education. Probably because of that no statistical difference was found regarding academic year and acquisition of knowledge allowing a joint analysis.

\subsection{Instrument}

The project team applied standardized pre- and post-tests online before and after applying all cases. The pre- and post-test contained three main questions about SDGs (What is sustainable development? Are you familiar with the United Nation's 2030 Agenda for Sustainable Development? Rate your knowledge about sustainable development on the below scale). In both tests the same metrics were collected: gender, age, level and field of study, and nationality. Some multiple-choice questions were aligned with the post-test tool, and open questions were added at the end of this test. However, the group of questions in which we tested respondents' knowledge and beliefs about sustainable development and 
the UN 2030 Agenda for Sustainable Development was unchanged in pre-test and post-test (Appendix A).

It took around 5 to $10 \mathrm{~min}$ for students to answer the questionnaire, but the application was not timed in each country. We asked all students participating in the course to complete pre-tests a week before the sessions. After the case-based application, instructors send the post-tests to the students to be filled within $24 \mathrm{~h}$. The tests were implemented through two platforms: MS Forms (Poland and Sweden) and Google Forms (Greece and Portugal). These evaluation tools were developed jointly, so they were the same in all the testing countries. The questions were supported in the literature review, and some (only in the post-test) were directed to the teaching methodology used. Besides this content validation, the reliability of the instruments was done by team members that read, answered and improved the tests until a consensus among all was achieved. The pre-test and a post-test were translated into national languages in order to make them as intuitive as possible for the students (the exception were students from Sweden, who solved the questionnaires in English because the sessions were applied in a course taught in English). Also, instructors completed a qualitative self-assessment which was used as a supportive evaluation to better understand the procedure undertaken in each location, but the analysis if this data are not the subject of this paper.

\subsection{Procedure}

We applied different cases in different countries as convenient to the country instructors' expertise, available time and according to the content and background of the higher education students (Table 2). Students participation was voluntary or integrated in course classes as part of the curricular content.

Table 2. Cases and countries of application.

\begin{tabular}{ccccc}
\hline Cases Titles & Poland & Greece & Portugal & Sweden \\
\hline $\begin{array}{c}\text { Dead wood in the Białowieża Forest } \\
\text { Organic olive cultivation in Messinian } \\
\text { Mani, Peloponnese }\end{array}$ & $(n=7)$ & & & $(n=21)$ \\
$\begin{array}{c}\text { Transformation of a local production company } \\
\text { into a sustainable business }\end{array}$ & & $(n=16)$ & \\
$\begin{array}{c}\text { Sustainable food consumption- mitigating } \\
\text { food waste }\end{array}$ & & & \\
$\begin{array}{c}(n=14) \\
\text { Remodelling an ancient farm in Portugal }\end{array}$ & & $(n=22)$ & $(n=18)$ \\
\hline
\end{tabular}

Due to the COVID-19 pandemic, PASSION team had to reformulate the educational resources into online teaching and both applications of the tests had to be re-planned. Despite that, the time for the teaching sessions was the same in all countries and all sessions were presented online. Participants fulfilled the tests online and voluntarily, and all the data collected was subject to analysis, following the international ethical standards extended to the social sciences research.

\section{Results}

The pre- and post-tests analysis of all cases indicates a significant improvement of sustainable development knowledge considering the three main questions in pooled dataset $\left(\mathrm{t}_{103}=-7.324 ; p=0.000\right)$ applied to the 104 participants.

In the pre-test a question was made regarding the place where participants had learned more about sustainable development. It was not surprising to find that 73 participants (70\%) referred to higher education, $41(39 \%)$ referred to secondary school and only $32(30 \%)$ named social media. Only one participant declared that he/she had never learned about this subject.

Regarding the three behaviours that contribute the most to sustainable development not many changes were found between pre- and post-tests. In the pre-test, higher education 
students rated those behaviours as the following: (i) thinking responsibly about what you are buying and where it's come from, not buying more than you need/responsible consumerism ( $n=53 ; 50 \%$ ); (ii) recycling and reusing ( $n=49 ; 47 \%)$; (iii) reducing waste, including not littering, zero waste, avoiding packaging, food waste $(n=47 ; 45 \%)$. The answers in the post-test were similar: (i) recycling and reusing $(n=49 ; 47 \%)$; (ii) thinking responsibly about what you are buying and where it has come from, not buying more than you need/responsible consumerism ( $n=43 ; 41 \%$ ); (ii) reducing waste, including not littering, zero waste, avoiding packaging, food waste $(n=36 ; 35 \%)$.

In respect of competencies related to sustainable development, students had equal answers in both tests, but 38 students (37\%) did not answer these questions. The most rated competency was systems-thinking (thinking of Earth as a complex system with close connections between the environmental, social, and economy issues), with 19 answers $(18,32 \%)$ in the pre-test and $21(20 \%)$ in the post-test. The less important competency mentioned in both tests was the normative competence (understanding the norms and values that underlie human actions even in a context of conflicting interests, compromises, and contradictions) with 17 answers (16\%) in the pre-test and $16(15 \%)$ in the post-test.

Concerning the question about which strategies are the most effective in developing knowledge, awareness, and competencies in sustainability, in both tests, students referred as the most important "presenting sustainable cases/dilemmas" (pre-test: $n=77(74 \%)$; post-test: $n=65(63 \%))$.

Due to the COVID-19 pandemic, the application of the cases to a wider number of students was restricted, making it almost impossible to compare results between the countries. However, after further analysis considering the same three main questions, more significant results were found in four cases: (i) Remodelling an ancient farm in Portugal applied in Greece $(n=22)$; Dead wood in the Białowieża Forest applied to 21 Swedish students; Organic olive cultivation in Messinian Mani, Peloponnese taught in Greek classes to 16 students, and Transformation of a local production company into a sustainable business administrated in Poland $(n=14)$.

The case concerning the remodelling of an ancient farm in Portugal applied in Greece gave the strongest effect $(\mathrm{Z}=-3.712 ; p=0.000)$. The case concerning biodiversity of the Białowieża Forest in Poland used in Sweden also have a strong impact on their knowledge $(\mathrm{Z}=-2.531 ; p=0.011)$. The case concerning organic agriculture implemented in Greece to 16 participants gave collectively a slightly weaker effect $(Z=-2.232 ; p=0.026)$. Finally, the case concerning the transformation of a local production company into a sustainable business in Polish conditions and implemented in Poland to a sample of 14 participants resulted in the weakest but still significant outcome $(Z=2.880 ; p=0.040)$.

Regarding these four cases where results were significant in the three main questions, a more in-depth analysis was conducted to some open questions of the post-test made to the 73 students involved. One post-test open question was related to the SDGs that students learned during the development of the case. Surprisingly, although in the lesson plan only some goals were expected to be achieved, students mentioned the achievement of all 17 goals in three cases: "Remodelling an ancient farm in Portugal", "Dead wood in the Białowieża Forest in Poland" and "Organic olive cultivation in Messinian Mani, Peloponnese". In the case "Transformation of a local production company into a sustainable business" only four goals were not mentioned: goal 2-zero hunger; goal 5-gender equality; goal 14-life below water and goal 16-peace and justice. The results reflect not only the cross-country character of the cases as well as the appropriateness of the chosen thematic for the cases. Moreover, concerning the relevance of the thematic, the analysis of another open question showed that 64 participants $(88 \%)$ mentioned them as relevant. When asked about the pillar of sustainability-related to the case developed in the sessions, and although having lots of not respondents, many students $(n=48 ; 66 \%$ of the respondents) related the case to the environmental dimension of sustainable development. Others mentioned the economic dimension ( $n=46 ; 63 \%$ of the respondents) and few ( $n$ $=41 ; 56 \%$ of the respondents) referred to the social dimension. The results reflect the 
integration of the three pillars of sustainable development in the cases, which was intended to lead students to understand that sustainable development involves more than just environmental issues.

The teaching methodology was considered adequate to understand the concept of sustainable development by 69 students ( $94 \%$ of the respondents). The majority of students consider that the session allowed them to cooperate with peers ( $n=39 ; 49 \%)$, and, simultaneously, they reject both the assumption that the case was boring ( $n=36 ; 49 \%$ ) or that they were unable to express their opinions $(n=50 ; 69 \%)$. Nevertheless, only $27(37 \%)$ out of the 73 students that answer this final question considered that this methodology motivated them to do their best.

\section{Discussion}

As mentioned, the pre- and post-tests analysis of all cases revealed a significant improvement in the 104 participants regarding the knowledge about sustainable development after the application of the case-based teaching sessions. Similar results have been obtained in a study [48] that concerned sustainable food applied among third year students of the degree in Early Childhood Education. The students greatly improved their sustainability competences after a period of didactic training with the projec methodology. Although being a different teaching methodology it seems that the involvement of students with strategies and resources directed to SDGs helps them to improve knowledge. Some authors [49] underscored the potential of case-based approaches in equipping students to encounter complexity, manage uncertainty, and generate innovative strategies in sustainability perspective. Our results confirm this potential. Moreover, a cross-country approach confirms the universality of carefully selected cases in improving sustainability competencies among students.

It was not surprising to confirm that students' answers regarding the place where they had learned more about sustainable development was in higher education. The thematic SDGs in not very explored yet in middle or secondary education and is still the higher education system that gets more involved in its teaching. Higher education's sustainability curriculum is a critical level for developing graduates' abilities and knowledge to handle the interwoven social, ecological, and economic concerns of the twenty-first century in their professional and personal lives [50]. It is interesting to note that school textbooks rarely refer to SDGs neither as a specific topic nor aligned it in other content knowledge like, for example, biodiversity or natural resources. Although mass media are commonly used to disseminate the knowledge, and informal learning shows promising potential to foster motivation and fascination and to increase system knowledge [50], formal learning is still the one that supports best the acquisition and consolidation of knowledge. An interesting example of broader application of case-based learning can be found in a Michigan Sustainability Cases initiative [51]. It builds on case-based approach to support active and engaged learning resorting to the: integration of audiovisual elements into text-based case narratives; strong partnerships among students, faculty, and practitioners to flip the curriculum; and a digital platform allowing flexibility in configuring case-based curriculum design.

Regarding the three behaviours that contribute the most to sustainable development (responsible consumerism; recycling and reusing; reducing waste) the few changes observed between pre- and post-tests are probably related with the topics of the cases applied and even the background of the students. Students had also equal answers in respect of the development of the system thinking as the main competency in the four cases. As stated by some authors [52] "Learning about sustainability involves more than being able to find sustainable solutions to a single problem. It means developing the ability to think about complex human environmental systems...". The development of key competencies in sustainability among students from different fields of higher education demands an interdisciplinary view on solving real-world problems [53]. This in turn requires both greater familiarity with interdisciplinarity among academic teachers as well as students' self-responsibility in acquiring those competencies. Developing boundary-crossing skills 
among students allowing for attaining an interdisciplinary perspective is however difficult task [54].

Students also mentioned the acknowledgement of all goals after the application of the individual cases. It seems this experience was their first engagement with SDGs making very difficult the identification of a specific goals. On the other hand, cases were less focused in specific SDS as expected. After a second look to the sessions plans of the cases, we realized that questions raised after the presentation of the case should be more SDGs focused so as to direct student to embrace specific goals. It is important to remind that all cases were applied with similar lesson plans, in more or less the same time and by teachers that were instructed to have a similar procedure. Aligned with these facts students also mentioned that the strategies of "presenting sustainable cases/dilemmas" are the best ones to develop SDGs. That statement seems to corroborate the previous finding: if it is the first time they learned about it, it is also the only way they have learned about SDGs. On the other hand, it also validates the significant impact the case-based methodology had in the 73 students participating in the four case-based sessions, since we used cases and dilemmas to explore the diverse topics.

The teaching methodology was considered adequate to understand the concept of sustainable development, but few students pointed out that it stimulated them to do their best. This fact is probably related to the lack of familiarity of students and instructors to use the case-based teaching methodology, especially in a remote environment. Studies show that face-to-face discussions provide more social opportunities for students to construct shared understandings, to consider multiple perspectives and generates more efficient discussion that the online environment [55]. Literature also reveals that students should be able to use their classroom time to satisfy their real-life demands $[21,56]$. By learning with real case students develop the required citizen's ability to diagnose a crisis, analyse and discuss several options, and make a final decision, which is considered vital for sustainable development.

\section{Conclusions}

This study showed the impact of case-based teaching online sustainable-development sessions in four countries. Specifically, this study focused on analysing students' responses to a test presented before and after class instruction. Results were only significant with cases applied in four countries, because other country samples were too small to allow further statistical analysis. The COVID-19 pandemic was an epistemological obstacle to the implementation of the cases in face-to-face sessions with a large group of students. This fact made it impossible to make a wider comparison in this cross-country case-based study on teaching sustainable development goals to university students As suggestions for further research, we can recommend face-to-face sessions, exploitation of new cases and larger samples making possible a wider cross-country analyses.

The results indicate that the case-based teaching improved the knowledge of sustainable development goals, which are expected to be reflect in some positive changes in pro-environmental behaviours. Our study also enhanced social and economic issues that were also raised and assimilated by the higher education students in all countries that participated. We also point out the potential of case-based teaching methodology to be applied in a cross-country manner. Although being applied in remote environment, this methodology captivated the motivation of students to learn about sustainable development and fulfilled its goal with a positive impact. Summarizing, our findings showed: (1) the interdisciplinarity of sustainable development goals and how easily they can be aligned to real worldwide cases; (2) that students learning with case-based teaching tend to present positive responses to sessions' comprehension, demonstrating an increase of SDGs knowledge and (3) that case-based teaching raises as a rather eclectic way of addressing real situations from the daily life to discuss and increase knowledge that is needed to boost attitudes and pro-environmental behaviours. 
Author Contributions: Conceptualization, C.V., J.S., C.S.C.C., G.M., K.I., I.G.S. and K.K.; methodology, C.V., J.S., C.S.C.C., G.M., K.I., I.G.S. and K.K.; software, SPSS treatment, C.V.; validation, C.V., J.S., C.S.C.C., G.M., K.I., I.G.S. and K.K.; formal analysis, C.V. and J.S.; investigation, C.V., J.S., C.S.C.C., G.M., K.I., I.G.S. and K.K.; resources, C.V., J.S., C.S.C.C., G.M., K.I., I.G.S. and K.K.; writing-original draft preparation, by C.V. and J.S.; writing-review and editing, C.V., J.S., C.S.C.C., G.M., K.I., I.G.S. and K.K.; supervision, K.I.; project administration, K.I.; funding acquisition, K.I. All authors have read and agreed to the published version of the manuscript.

Funding: This research was funded by NAWA, grant number PPI/APM/2019/1/00096/DEC/01.

Institutional Review Board Statement: Ethical review and approval were waived for this study due to voluntary participation of the sample where all members had more than 18 years old. The data were collected anonimously and confidential.

Informed Consent Statement: Participants were informed about the aims of the study and agreed to allow the research team to use the data to write this paper.

Data Availability Statement: Data is contained within the article.

Acknowledgments: To all members of PASSION team who helped the development and validation of the survey and the cross-country application of the case-based teaching sessions. Portuguese team is thankful to Fundação para a Ciência e Tecnologia (FCT) within the scope of UIDB/04423/2020 and UIDP $/ 04423 / 2020$.

Conflicts of Interest: The authors declare no conflict of interest.

\section{Appendix A}

Pre-Test

i. $\quad$ Case title: [Open answer]

ii. Fictional name: [Open answer]

iii. Age on 31st December 2020: [Open answer]

iv. Gender: Male [ ]/Female [ ]/Other [ ]

v. Country: [Open answer]

vi. Course: Bachelor's in [Open answer]/Master's in [Open answer]

vii. Academic background: Graduated in [Open answer]

1. What is sustainable development? Selected the definition you most agree with.

a. Sustainable development is the development that allows our needs to be met while being aware of the environmental, social and economic limitations we face. [ ]

b. Sustainable development is the development that meets the needs of the present without compromising the ability of future generations to meet their own needs. [ ]

c. Sustainable development is maintaining a balance between the human need to improve lifestyles and the preservation of natural resources and ecosystems. [ ]

d. If you don't agree with the definitions of sustainable development and have your own, please write your comment here. [Open answer]

2. Are you familiar with the United Nation's 2030 Agenda for the Sustainable Development? Yes [ ]/No [ ]

2.1 If you are, name three of its goals. [Open answer]

3. Where did you learn about sustainable development? You can select multiple answers.
a. Primary School [ ]
b. Secondary School [ ]
c. Higher Education [ ]
d. Family []
e. Friends [ ]
f. Social Media [ ]
g. TV [] 


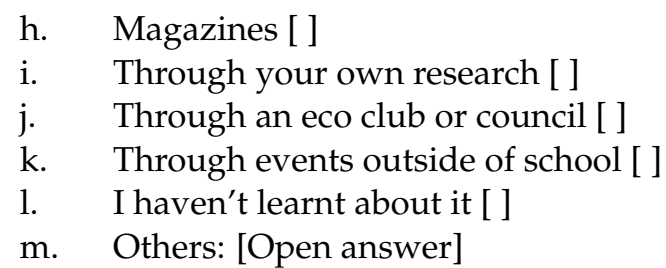

4. In your opinion which three of the following behaviours contribute the most to sustainable development?

a. Reducing Plastic use, including micro-plastics and single use plastics [ ]

b. Reducing Waste, including not littering, zero waste, avoiding packaging, food waste [ ]

c. Donating to charity [ ]

d. Having a Plant based diet [ ]

e. Thinking responsibly about what you are buying and where it's come from, not buying more than you need/Responsible Consumerism [ ]

f. Nothing, the Businesses and Governments need to make the change [ ]

g. Save Energy, Turn off Lights and Appliances [ ]

h. Cycling/Walking/Using Public Transport instead of a Car [ ]

i. Raising other people's awareness/Campaigning [ ]

j. Protesting [ ]

k. Not Flying [ ]

1. Voting Green

m. Buying local produce or growing your own [ ]

n. Recycling and Reusing [ ]

o. Using Green/Renewable energy [ ]

5. Order, from 1 (least important) to 5 (most important), the importance of the following competencies?

a. Thinking of Earth as a complex system with close connections between environment, social issues and economy (systems-thinking competence) [ ]

b. Predicting the consequences of Human actions in environment, society and economy of planet Earth (anticipatory competence) [ ]

c. Understanding the norms and values that underlie Human actions even in a context of conflict of interests, compromises and contradictions (normative competence) []

d. Developing and implementing strategic collective actions (strategic competence) [ ]

e. Collaborating and communicating to better negotiate across diverse cultures and social groups (interpersonal competence) [ ]

6. Which of the following strategies do you think are the most effective in developing knowledge, awareness and competencies in sustainability? Choose only three.

a. Presenting sustainable cases/dilemmas [ ]

b. Participating in group work [ ]

c. Raising critical questions [ ]

d. Clarifying one's own values [ ]

e. Being involved in discussions [ ]

f. $\quad$ Listening to lectures [ ]

g. Participating in study visits or field [ ]

7. How would you rate your knowledge about sustainable development being 1 (not enough) and 5 (excellent)? Not enough (1)/2/3/4/Excellent (5) 


\section{References}

1. United Nations. Transforming our World: The 2030 Agenda for Sustainable Development (A/RES/70/1). 2015. Available online: https://goo.gl/ImNES4 (accessed on 23 June 2021).

2. Annan-Diab, F.; Molinari, C. Interdisciplinarity: Practical approach to advancing education for sustainability and for the Sustainable Development Goals. Int. J. Manag. Educ. 2017, 15, 73-83. [CrossRef]

3. Stafford-Smith, M.; Griggs, D.; Gaffney, O.; Ullah, F.; Reyers, B.; Kanie, N.; Stigson, B.; O'Connell, D. Integration: The key to implementing the Sustainable Development Goals. Sustain. Sci. 2017, 12, 911-919. [CrossRef] [PubMed]

4. Lemos, M.C.; Agrawal, A. Environmental governance. Annu. Rev. Environ. Resour. 2006, 31, 297-325. [CrossRef]

5. Agbedahin, A.V. Sustainable development, Education for Sustainable Development, and the 2030 Agenda for Sustainable Development: Emergence, efficacy, eminence, and future. Sustain. Dev. 2019, 27, 669-680. [CrossRef]

6. García-González, E.; Jiménez-Fontana, R.; Azcárate, P. Education for Sustainability and the Sustainable Development Goals: Pre-Service Teachers' Perceptions and Knowledge. Sustainability 2020, 12, 7741. [CrossRef]

7. Kioupi, V.; Voulvoulis, N. Education for sustainable development: A systemic framework for connecting the SDGs to educational outcomes. Sustainability 2019, 11, 6104. [CrossRef]

8. UNESCO. Education for Sustainable Development Goals: Learning Objectives; UNESCO. 2017. Available online: https://bit.ly/ 3wofCQX (accessed on 23 June 2021).

9. Vázquez-Verdera, V.; Domingo, J.; Dura, E.; Gabaldón-Estevan, D.; López-Baeza, E.; López, S.M.; Martínez-García, E. The Future We Want: A Learning Experience to Promote SDGs in Higher Education from the United Nations and University of Valencia. Sustainability 2021, 13, 8550. [CrossRef]

10. Vasconcelos, C.; Orion, N. Earth Science Education as a Key Component of Education for Sustainability. Sustainability 2021, 13, 1316. [CrossRef]

11. Metzger, E.; Gosselin, D.; Orr, C.H. Quality Education. In Geosciences and the Sustainable Development Goals; Joel, C.G., Smith, M., Eds.; Springer Nature: Berlin/Heidberg, Germany, 2021; pp. 81-104.

12. Kollmuss, A.; Agyeman, J. Mind the gap: Why do people act environmentally and what are the barriers to pro-environmental behaviour? Environ. Educ. Res. 2002, 8, 239-260. [CrossRef]

13. Zguir, M.F.; Dubis, S.; Koc, M. Embedding Education for Sustainable Development (ESD) and SDGs values in curriculum: A comparative review on Qatar, Singapore and New Zealand. J. Clean. Prod. 2012, 319, 128534. [CrossRef]

14. Griffiths, T.G. Education to transform the world: Limits and possibilities in and against the SDGs and ESD. Int. Stud. Sociol. Educ. 2021, 30, 73-92. [CrossRef]

15. Bell, D.V. Twenty First Century Education: Transformative Education for Sustainability and Responsible Citizenship. J. Teach Educ. Sustain. 2021, 18, 48-56. [CrossRef]

16. Činčera, J.; Mikusiński, G.; Binka, B.; Calafate, L.; Calheiros, C.; Cardoso, A.; Hedblom, M.; Jones, M.; Koutsouris, A.; Vasconcelos, C.; et al. Managing Diversity: The Challenges of Inter-University Cooperation. Sustainability Education. Sustainability 2019, 11, 5610. [CrossRef]

17. Vasconcelos, C.; Schneider-Voß, S.; Peppoloni, S. Teaching Geoethics: Resources for Higher Education; U. Porto Edições: Porto, Italy, 2020.

18. Merseth, K. The early history of case-based instruction: Insights for teacher education today. J. Teach. Educ. 1991, 42, 243-249. [CrossRef]

19. Vasconcelos, C.; Faria, J.; Cardoso, A. Sustainability and case-based methodology. In Widening Interdisciplinary Sustainability, Iwińska, K.; Jones, M., Kraszewska, M., Eds.; Collegium Civitas: Warsaw, Poland, 2018; p. 18.

20. Schank, R.C. Case-based teaching: Four experiences in educational software design. Interactive. Learn. Environ. 1990, 1, $231-253$. [CrossRef]

21. Vasconcelos, C.; Faria, J. Case-Based Curricula Materials for Contextualized and Interdisciplinary Biology and Geology Learning. In Contextualizing Teaching to Improving Learning: The Case of Science and Geography; Leite, L., Dourado, L., Afonso, A., Morgado, S., Eds.; Nova Science Publishers: Hauppauge, NY, USA, 2017; pp. 245-260.

22. Gravett, S.; Beer, J.; Odendaal-Kroon, R.; Merseth, K.K. The affordances of case-based teaching for the professional learning of student-teachers. J. Curric. Stud. 2017, 49, 369-390. [CrossRef]

23. Heitzmann, R. Case study instruction in teacher education: Opportunity to develop students' critical thinking, school smarts and decision making. Education 2018, 128, 523-541.

24. Kunselman, J.; Johnson, K. Using the case method to facilitate learning. College Teach. 2004, 52, 87-92. [CrossRef]

25. Haley, M.H. Implications of using case study instruction in a foreign/second language methods course. Foreign Lang. Ann. 2004, 37, 290-300. [CrossRef]

26. Sato, M.; Rogers, C. Case Methods in Teacher Education; Elsevier: Oxford, UK, 2010.

27. Shulman, L.S. The Wisdom of Practice; Jossey-Bass: San Francisco, CA, USA, 2004.

28. Annadani, R.R.; Undi, M. A study to assess the effectiveness and perception of students regarding Case Based Learning over traditional teaching method in Community Medicine. Indian J. Community Health 2021, 33, 41-46. [CrossRef]

29. Williams, B. Case-based learning-a review of the literature: Is there scope for this educational paradigm in pre- hospital education? Emerg. Med. J. 2005, 22, 577-581. [CrossRef] [PubMed] 
30. Harrington, H.L.; Garrison, J.W. Cases as shared inquiry: A dialogical model of teacher preparation. Am. Educ. Res. J. 1992, 29, 715-735. [CrossRef]

31. McNaught, C.; Lau, W.; Lam, P.; Hui, M.; Au, P. The dilemma of case-based teaching and learning in science in Hong Kong: Students need it, want it, but may not value it. Int. J. Sci. Educ. 2012, 27, 1017-1036. [CrossRef]

32. Giacalone, D. Enhancing student learning with case-based teaching and audience response systems in the MSc. Course "Food Innovation and Health". In Improving University Science Teaching and Learning: Pedagogical; Department of Science Education University of Copenhagen: Copenhagen, Danish, 2015; pp. 351-367.

33. Doran, J.; Healy, M.; Mccutcheon, M.; O'Callaghan, S. From Beyond the Grade: Reflections on Assessments in the Context of Case-Based Teaching. Ir. J. Manag. 2011, 31, 3-19.

34. Merserth, K. Cases and case methods in teacher education. In Handbook of Research on Teacher Education; Sikul, J., Ed.; Simon \& Schuster: New York, NY, USA, 1996; pp. 722-744.

35. Giangrande, N.; White, R.M.; East, M.; Jackson, R.; Clarke, T.; Coste, M.S.; Penha-Lopes, G. A competency framework to assess and activate education for sustainable development: Addressing the UN sustainable development goals 4.7 challenge. Sustainability 2019, 11, 2832. [CrossRef]

36. Iwińska, K.; Jones, M.; Kraszewska, M.; Civitas, C. (Eds.) Widening Interdisciplinary Sustainability Education; Collegium Civitas: Warsaw, Poland, 2018.

37. Blicharska, M.; Angelstam, P.; Giessen, L.; Hilszczański, J.; Hermanowicz, E.; Holeksa, J.; Jacobsen, J.B.; Jaroszewicz, B.; Konczal, A.; Konieczny, A.; et al. Between biodiversity conservation and sustainable forest management-A multidisciplinary assessment of the emblematic Białowieża Forest case. Biol. Conserv. 2020, 248, 108614. [CrossRef]

38. Mikusiński, G.; Bubnicki, J.W.; Churski, M.; Czeszczewik, D.; Walankiewicz, W.; Kuijper, D. Is the impact of loggings in the last primeval lowland forest in Europe underestimated? The conservation issues of Białowieża Forest. Biol. Conserv. 2018, 227, 266-274. [CrossRef]

39. Brzezina, N.; Biely, K.; Helfgott, A.; Kopainsky, B.; Vervoort, J.; Mathijs, E. Development of organic farming in europe at the crossroads: Looking for the way forward through system archetypes lenses. Sustainability 2017, 9, 821. [CrossRef]

40. Kolb, D.A. Experiential Learning: Experience as the Source of Learning and Development; Prentice Hall: Upper Saddle River, NJ, USA, 1984

41. Schmitz, C.; van Meijl, H.; Kyle, P.; Nelson, G.C.; Fujimori, S.; Gurgel, A.; Valin, H. Land-use change trajectories up to 2050: Insights from a global agro-economic model comparison. Agric. Econ. 2014, 45, 69-84. [CrossRef]

42. Crenna, E.; Sinkko, T.; Sala, S. Biodiversity impacts due to food consumption in Europe. J. Clean. Prod. 2019, $227,378-391$. [CrossRef]

43. Montoya, D.; Gaba, S.; de Mazancourt, C.; Bretagnolle, V.; Loreau, M. Reconciling biodiversity conservation, food production and farmers' demand in agricultural landscapes. Ecol. Model. 2020, 416, 108889. [CrossRef] [PubMed]

44. Martínez, J.M.G.; Martín, J.M.M.; Fernández, J.A.S.; Mogorrón-Guerrero, H. An analysis of the stability of rural tourism as a desired condition for sustainable tourism. J. Bus. Res. 2019, 100, 165-174. [CrossRef]

45. Rosalina, P.D.; Dupre, K.; Wang, Y. Rural tourism: A systematic literature review on definitions and challenges. J. Hosp. Tour. Manag. 2021, 47, 134-149. [CrossRef]

46. Raworth, K. Doughnut Economics: Seven Ways to Think Like a 21st-Century Economist; Chelsea Green Publishing: White River Junction, VT, USA, 2017.

47. Jabłonska-Porzuczek, L. Situation of disabled people in the Polish labor market. Ann. Pol. Assoc. Agric. Agrobusiness Econ. 2019, 21, 143-153. [CrossRef]

48. Fuertes-Camacho, M.T.; Graell-Martin, M.; Fuentes-Loss, M.; Balaguer-Fabregas, M.C. Integrating sustainability into higher education curricula through the project method, a global learning strategy. Sustainability 2019, 11, 767. [CrossRef]

49. Sprain, L.; Timpson, W.M. Pedagogy for sustainability science: Case-based approaches for interdisciplinary instruction. Environ. Commun. 2012, 6, 532-550. [CrossRef]

50. Holdsworth, S.; Sandri, O. Investigating undergraduate student learning experiences using the good practice learning and teaching for sustainability education (GPLTSE) framework. J. Clean. Prod. 2021, 311, 127532. [CrossRef]

51. Hardin, R.; Bhargava, A.; Bothner, C.; Browne, K.; Kusano, S.; Golrokhian, A.; Wright, M.; Agrawal, A. Towards a revolution in sustainability education: Vision, architecture, and assessment in a case-based approach. World Dev. Perspect. 2016, 1, 58-63. [CrossRef]

52. Brennan, C.; Molloy, O. A system dynamics approach to sustainability education. Syst. Res. Behav. Sci. 2020, 37, 875-879. [CrossRef]

53. Barth, M.; Godemann, J.; Rieckmann, M.; Stoltenberg, U. Developing key competencies for sustainable development in higher education. Int. J. Sustain. High. Educ. 2007, 8, 416-430. [CrossRef]

54. Spelt, E.J.H.; Biemans, H.J.A.; Tobi, H.; Luning, P.A.; Mulder, M. Teaching and learning in interdisciplinary higher education: A systematic review. Educ. Psychol. Rev. 2009, 21, 365-378. [CrossRef]

55. Akbulut, M.S.; Hill, J.R. Case-Based Pedagogy for Teacher Education: An Instructional Model. Contemp. Educ. Technol. 2020, 12, 134-149. [CrossRef]

56. Ulvik, M.; Eide, H.M.K.; Eide, L.; Helleve, I.; Jensen, V.S.; Ludvigsen, K.; Torjussen, L.P.S. Teacher educators reflecting on case-based teaching-A collective self-study. Prof. Dev. Educ. 2020, 1-15. [CrossRef] 